\title{
Belgeo
}

Revue belge de géographie

\section{Argillipedoturbation and the development of rock fragment covers on Vertisols in the Ethiopian Highlands}

L'argillipédoturbation et le développement de la couverture pierreuse des vertisols sur les Hauts Plateaux éthiopiens

Jan Nyssen, Jan Moeyersons, Jean Poesen, Mitiku Haile and Jozef A. Deckers

\section{OpenEdition}

Electronic version

URL: http://journals.openedition.org/belgeo/16184

DOI: $10.4000 /$ belgeo.16184

ISSN: 2294-9135

\section{Publisher:}

National Committee of Geography of Belgium, Société Royale Belge de Géographie

\section{Printed version}

Date of publication: 30 June 2002

Number of pages: $183-194$

ISSN: 1377-2368

Electronic reference

Jan Nyssen, Jan Moeyersons, Jean Poesen, Mitiku Haile and Jozef A. Deckers, « Argillipedoturbation and the development of rock fragment covers on Vertisols in the Ethiopian Highlands ", Belgeo [Online], 2 | 2002, Online since 01 July 2002, connection on 19 April 2019. URL : http:// journals.openedition.org/belgeo/16184; DOI : 10.4000/belgeo.16184

This text was automatically generated on 19 April 2019

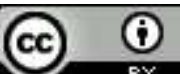

Belgeo est mis à disposition selon les termes de la licence Creative Commons Attribution 4.0 International. 


\title{
Argillipedoturbation and the development of rock fragment covers on Vertisols in the Ethiopian Highlands
}

\author{
L'argillipédoturbation et le développement de la couverture pierreuse des \\ vertisols sur les Hauts Plateaux éthiopiens
}

Jan Nyssen, Jan Moeyersons, Jean Poesen, Mitiku Haile and Jozef A. Deckers

This study is part of research programme G006598.N funded by the Fund for Scientific Research Flanders, Belgium. Financial support by the Flemish Interuniversity council (VLIR, Belgium) is acknowledged. Thanks go to Berhanu Gebremedhin Abay for assistance to all the fieldwork. Numerous farmers, the local Agricultural Office, REST (Relief Society of Tigray) branch and the authorities of the concerned villages and district facilitated the research.

\section{Introduction}

1 Rock fragment cover and content largely control hydrology, soil erosion and soil productivity in arid, semi-arid and sub-humid regions (Poesen \& Lavee, 1994). «Rock fragments» refers to all mineral particles $>5 \mathrm{~mm}$ in diameter. Especially on cropland, rock fragment cover (RC) forms an efficient protection against rill and interrill erosion (Wischmeier \& Smith, 1978; Römkens, 1985), which is mainly due to (1) reduction of soil erodibility by protection against raindrop impact and flow detachment; (2) reduction of physical soil degradation (surface sealing) and (3) retardation of runoff velocity, thus reducing detachment and transport capacity of the overland flow (Poesen et al., 1994). Although dense RC are an important feature in the fields of the Ethiopian Highlands, they did not receive due attention in soil erosion research. In his version of the Universal Soil Loss Equation, adapted to Ethiopian conditions, Hurni (1985) takes RC into account. 
However, he does not mention the evidence used to estimate the reduction of soil loss due to RC. With respect to rain infiltration into cultivated topsoils, Poesen \& Lavee (1994) indicated that rock fragments generally increase the infiltration rate by protecting the soil from raindrop impact, thus reducing surface sealing and crusting. In the study area, we observed water storage during rain showers in cavities under rock fragments and demonstrated that a high RC contributes to erosion control and better crop yields (Nyssen et al., 2001). Effects of rock fragment cover and content on productivity are usually positive in dry climatic conditions (Poesen \& Lavee, 1994). In the semi-arid areas of Ethiopia, moisture conservation techniques induce substantial increases in crop yield (Mitiku and Fassil, 1996). RC is thus a semi-natural factor that can partially control desertification.

2 Based on an earlier study of lateral and vertical rock fragment distribution in the Ethiopian Highlands, the following conclusions were reached (Nyssen et al., 2002a): with respect to the lateral displacement processes, one can distinguish between (1) lateral transport over the soil surface by trampling, tillage and concentrated flow, especially on steep slopes, and (2) rockfall from the cliffs. Vertical supply of rock fragments to the soil surface is caused by (1) selective runoff erosion and the concentration of lag deposits in erosion pavements, (2) tillage induced kinetic sieving, bringing preferentially large rock fragments $(>7.5 \mathrm{~cm})$ to the surface, even in the case of continuous fine sediment deposition and (3) argillipedoturbation in Vertisol areas.

The rock fragment mantle of Vertisols and soils with vertic properties, more upslope, is clearly in a state of development, as in some places new rock fragments rapidly appear at the surface after field clearing by the farmers. The objectives of this paper are (1) to assess the rates of rock fragment movement to the surface and rock fragment cover development, (2) to verify if the loci of emerging rock fragments show a spatial relation with the active polygonal structures of Vertisols (Nyssen et al., 2000), and (3) to analyse this apparent spatial relationship.

\section{Study area}

The Dogu'a Tembien district (Fig. 1), located in Tigray, on the rift shoulder to the west of the Danakil depression, was selected as research area for this study, since its elevation and morphology are typical for the Northern Ethiopian Highlands. Average rain depth is $760 \mathrm{~mm}$ y-1, occurring mainly between June and September. The Atbara-Takazze river system drains the water of the study area to the Nile. The population is mainly rural, as is more than $90 \%$ of the Ethiopian population. The district is situated some $50 \mathrm{~km} \mathrm{~W}$ of Mekelle, regional capital of Tigray. 
Figure 1. Map of the study area (1: Maidansi; 2: Zenako; 3: Adi Selam; 4: Enda Maryam, the blind head; and 5: confluence at kindergarten).
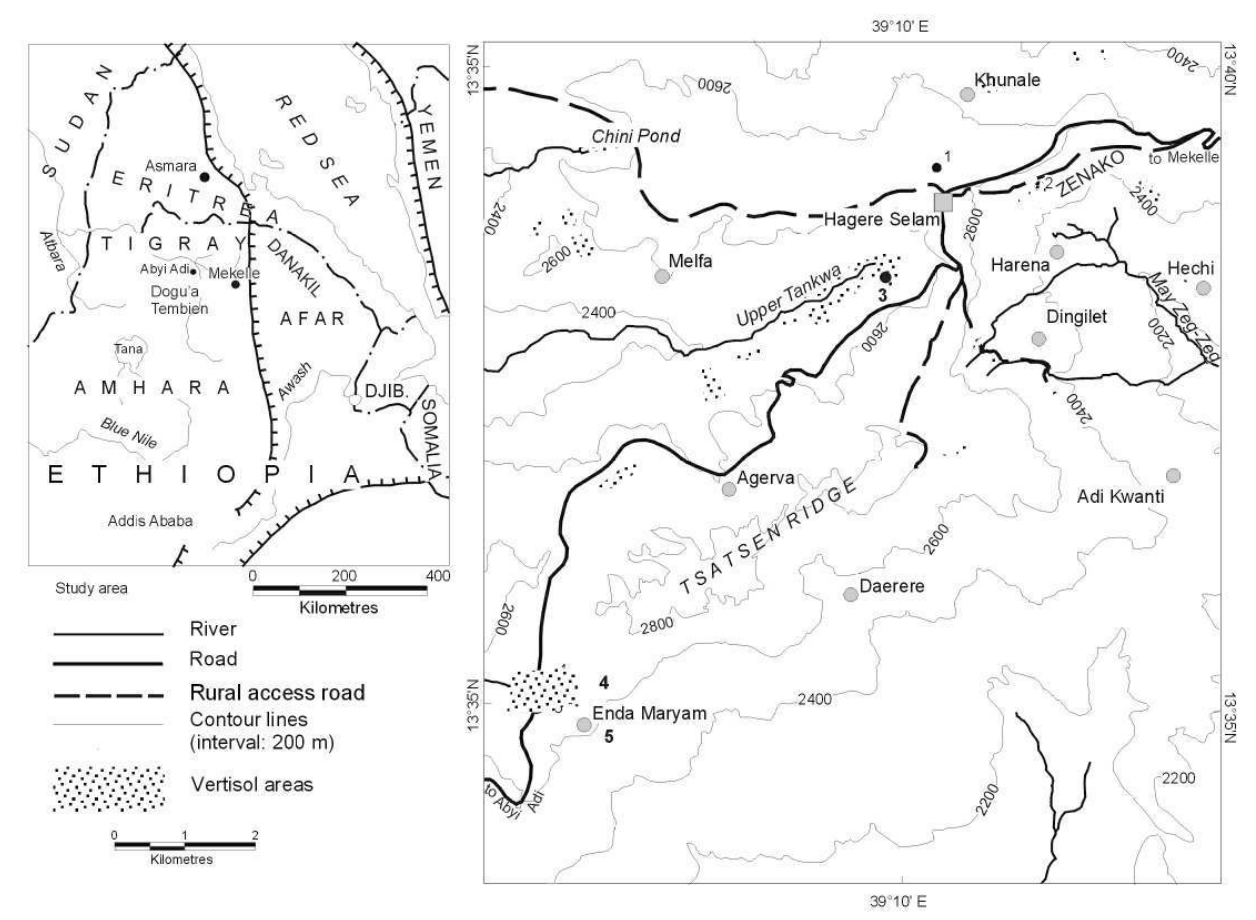

BASED ON ETHIOPIAN MAPPING AUTHORITY (1996) AND FIELD OBSERVATIONS.

Hagere Selam, the main town of the district, is located at an elevation of $2650 \mathrm{~m}$ a.s.l., on the road Mekelle-Abyi Adi. The relief of the study area is essentially linked to the subhorizontal structure of the lithology and to rapid incision (Mohr, 1963; Merla et al., 1979). The presence of faults and lineaments (lines of weakness) influences the pattern of the river systems. The uplift being recent, the rivers are in their youth stadium, and deeply incised.

Except for the dykes, all geological formations in the study area (Arkin et al., 1971; Beyth, 1972) contribute to the formation of a stepped morphology: (1) the Mesozoic sedimentary layers (Hutchinson \& Engels, 1970) are subhorizontal and present alternating hard and soft layers; (2) the basalt flows (Garland, 1980) are subhorizontal and interbedded with soft silicified lake deposits; (3) sills of Mekelle dolerite also form hard, subhorizontal layers. The relief thus consists of an alternation of flats and escarpments, expressing the unequal resistance of the rocks subjected to weathering. The edges of these scarps are nearly horizontal, underlining the tabular structure.

Due to the mountainous character of the district (Fig. 2) and to poverty-induced extensive agriculture, many soil erosion problems are encountered, which are at present somewhat tempered by an active soil conservation policy (Nyssen, 2001). 
Figure 2. View of the study area, looking Eastward from Hagere Selam, showing two typical catenas.

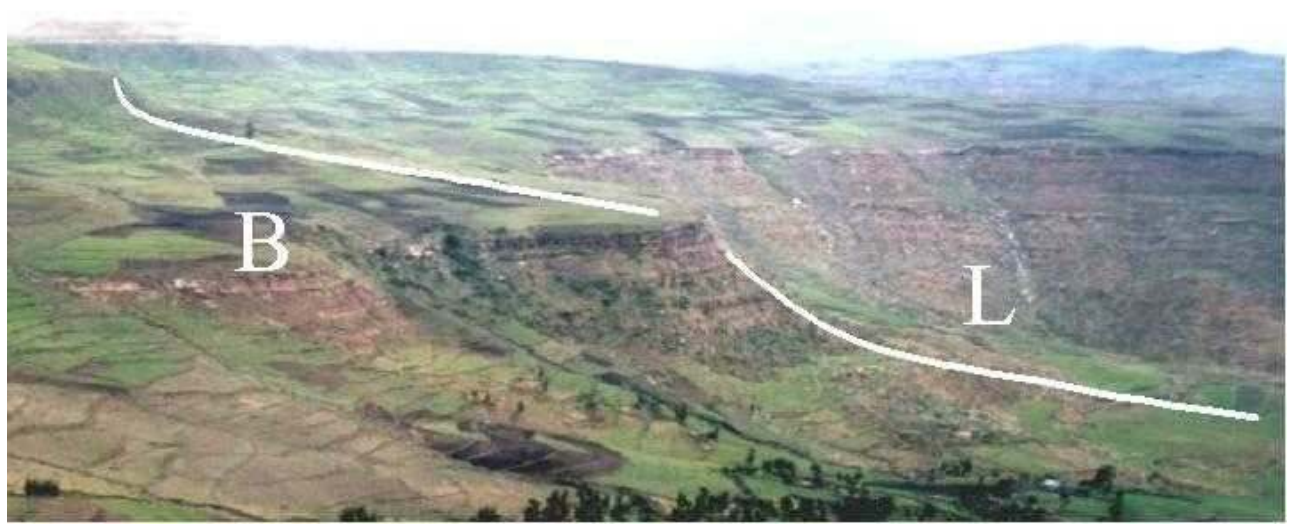

VERTISOLS gENERALLY OCCUR AT THE LOWER SIDE OF THE CATENA ON BASALT (B), AND SOMETIMES AT THE LOWER SIDE OF THE CATENA ON LIMESTONE (L).

PHOTO E. LAVRYSEN

Soil mapping in a 208 ha representative catchment (De Geyndt, 2001; Nyssen, 2001) revealed that $20.4 \%$ of its area is occupied by Vertisols (FAO et al., 1998). In the study area, Vertisol successions attributed to the Holocene (Brancaccio et al., 1997; Machado et al., 1998), often rest on or behind debris flow deposits (Nyssen et al., 2002b) and are, therefore, mostly underlain by material derived from the Tertiary basalt and from silicified lake deposits.

\section{Origin of the rock fragment covers}

The rock fragment cover of the Vertisols in Enda Maryam (Fig. 3) consists mainly of two mineralogical components. The first comprises chert fragments of all sizes up to $25 \mathrm{~cm}$. Many rock fragments are coated by a brownish-yellow or a whitish patina. The uncoated surfaces are often polished. Part of the chert debris are clearly prehistoric lithic artefacts, some of which are believed to be of Middle Stone Age type, more than $10 \mathrm{ky}$ old (Phillipson, 2000, 2001). The second component is whitish silicified shale. Their overall size varies between 5 and $15 \mathrm{~cm}$. Furthermore, the white shale also appears in a highly fragmented state as coarse sand, i.e. a loose mulch of fine granular aggregates in the upper part of the pedon (Blokhuis, 1982). Chert and silicified shale originate from the Tertiary lacustrine deposits, and form the bulk of the late Pleistocene mass movement material, underlying the Vertisol in Enda Maryam.

The coarse surface layer of Vertisols in Ethiopia is well known and often considered as a lag deposit or erosion pavement (Ahmad, 1996). But given the stratigraphic situation and the active Vertisol movements in the study area, the rock fragment cover has very probably been squeezed up as a consequence of swell-shrink cycles in the solum (argillipedoturbation, Hole, 1961). Similarly in areas were Vertisols developed on river 
terraces, the soil surface bears rounded rock fragments, which manifestly originate from the terrace and not from the nearby slopes.

Figure 3. Site at Enda Maryam where upward rock fragment movement was measured from 1999 to 2001.

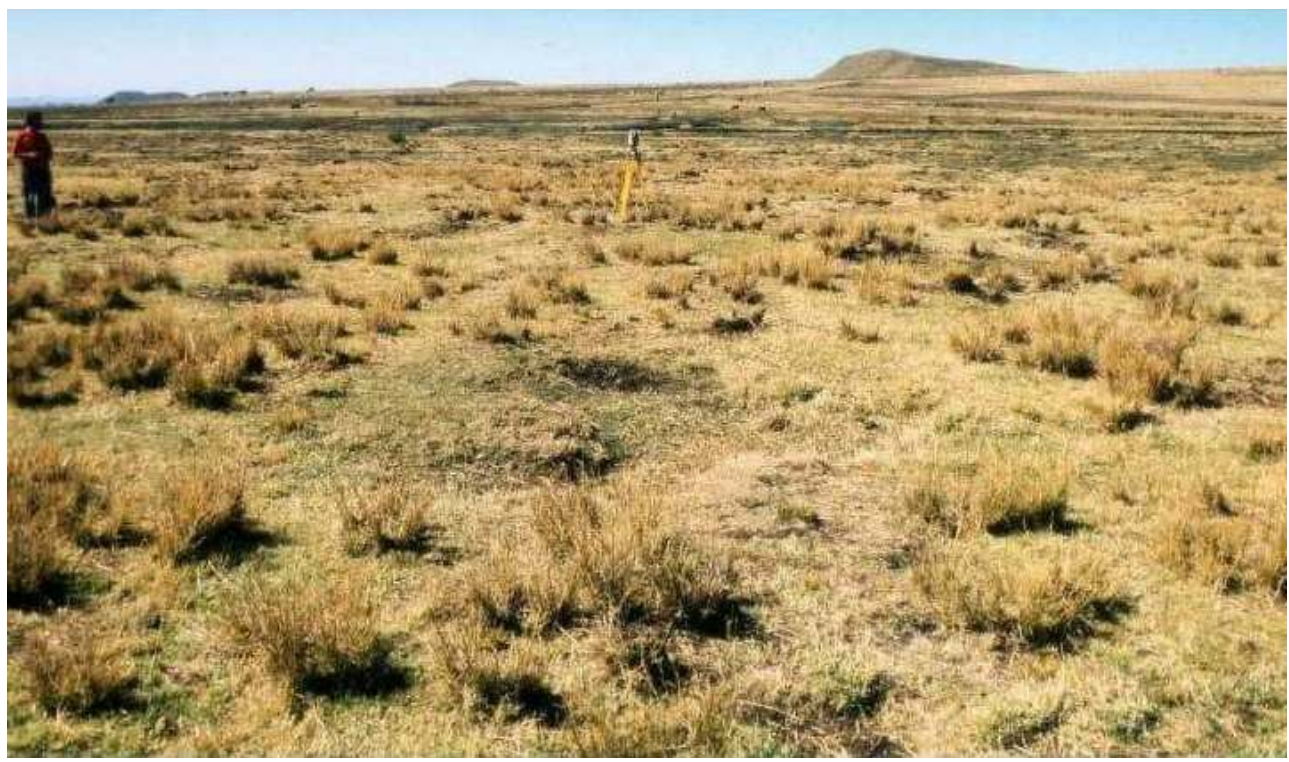

\section{Rates and spatial patterns of rock fragment transport to the soil surface}

11 A flat valley bottom confluence $\pm 100 \mathrm{~m}$ north of the Enda Maryam Kindergarten (Fig.1) was chosen as experimental site to assess the rate of rock fragment movement towards the soil surface. During the 1997-98 dry season, local people systematically removed the existing rock fragment cover to maintain the rural access road across the valley about 100 $\mathrm{m}$ upstream. The site seems appropriate to observe if new rock fragments have been squeezed to the surface: lateral supply of rock fragments by run-on is improbable as (1) the slope gradient is only $0.01 \mathrm{~m} \mathrm{~m}-1$, (2) the nearest slope $>0.05 \mathrm{~m} \mathrm{~m}-1$ is at least at a distance of $300 \mathrm{~m}$, (3) dispersed but well developed grassy tussocks hinder transport of rock fragments (Fig. 3), and (4) the rural access road also protects the site against runoff generated upslope. Tilting of rock fragments to the surface by ploughing can also be excluded as the place is only used for delayed grazing by cattle.

12 Polygonal structures ranged from 0.5 to $3 \mathrm{~m}$ in diameter in January 1999. Clear gilgai topography was absent, but the structures were formed by bundles of cracks, generally several $\mathrm{mm}$ to more than $2 \mathrm{~cm}$ wide at the surface.

13 Although the villagers affirmed that the site had been cleared completely in the 1997-1998 dry season, a number of rock fragments were visible at the soil surface in January 1999. They most probably resulted from upsqueezing over a period of about 1 year, including the rainy season of 1998. At the end of January 1999, all surface rock fragments with a visible surface greater than one $\mathrm{cm}^{2}$ were cleared in a circle of $5 \mathrm{~m}$ radius and their exact position was measured by theodolite. Out of the 294 rock fragments removed, 25 were larger than $10 \mathrm{~cm}$ and several measured more than $20 \mathrm{~cm}$. The farmers confirmed that they would not have overlooked so many large rock 
fragments for road construction. Most of the larger rock fragments we cleared were thus not yet visible at the soil surface during the dry season 1997-1998. Assuming that rock fragments less than $10 \mathrm{~cm}$ in size are not very interesting for road works and, therefore, were not systematically collected, we estimate that at least 10 large rock fragments became visible at the $78.5-\mathrm{m}^{2}$ experimental surface during the 1998 rainy season. In 1999, all rock fragments, either embedded or at the surface, were removed from the area. In 2000, exactly 100 rock fragments were again found embedded in the soil, with a total mass of $14.4 \mathrm{~kg}$ (Table 1). In 2001, 55 rock fragments with a total mass of $4.5 \mathrm{~kg}$ were collected from the same area. A very conservative estimation, without taking rock fragments lying at the surface into account, is that yearly, on average, 77 rock fragments, with a total mass of $8.5 \mathrm{~kg}$ are squeezed up to the surface of the cleared circle, i.e. one rock fragment $(0.11 \mathrm{~kg})$ per $\mathrm{m}^{2}$ per year. This indicates that the thick rock fragment pavements in Vertisol areas need many centuries to several thousands of years to be formed by argillipedoturbation. This first estimation is in agreement with the early Holocene age attributed to some of the Vertisols in the region (Brancaccio et al., 1997; Machado et al., 1998).

Table 1. Number of new rock fragments appearing at the surface of a $78.5 \mathrm{~m}^{2}$ circle in the Vertisol area of Enda Maryam, embedded (upper table), or lying on the surface (lower table).

\begin{tabular}{|c|c|c|c|c|c|c|c|}
\hline Embedded & & 2000 & & & 2001 & & Mean \\
\hline & Basalt & $\begin{array}{l}\text { Sil. } \\
\text { limest. (a) }\end{array}$ & Total & Basalt & $\begin{array}{l}\text { Sil. } \\
\text { limest. }\end{array}$ & Total & \\
\hline $\begin{array}{l}1-2 \mathrm{~cm} \\
2 \cdot 7.5 \mathrm{~cm} \\
>7.5 \mathrm{~cm} \\
\text { Total }\end{array}$ & $\begin{array}{l}0 \\
5 \\
1 \\
6\end{array}$ & $\begin{array}{l}9 \\
83 \\
2 \\
94\end{array}$ & $\begin{array}{l}9 \\
88 \\
3 \\
100\end{array}$ & $\begin{array}{l}0 \\
3 \\
0 \\
3\end{array}$ & $\begin{array}{l}9 \\
42 \\
1 \\
52\end{array}$ & $\begin{array}{l}9 \\
45 \\
1 \\
55\end{array}$ & $\begin{array}{l}9 \\
66.5 \\
2 \\
77.5\end{array}$ \\
\hline Surface & & 2000 & & & 2001 & & Mean \\
\hline & $\begin{array}{l}\text { Basalt } \\
\text { limest. }\end{array}$ & Sil. & Total & $\begin{array}{l}\text { Basalt } \\
\text { limest. }\end{array}$ & Sil. & Total & \\
\hline $\begin{array}{l}1-2 \mathrm{~cm} \\
2-7.5 \mathrm{~cm} \\
>7.5 \mathrm{~cm} \\
\text { Total }\end{array}$ & $\begin{array}{l}4 \\
4 \\
0 \\
8\end{array}$ & $\begin{array}{l}82 \\
64 \\
0 \\
146\end{array}$ & $\begin{array}{l}86 \\
69 \text { (b) } \\
0 \\
155\end{array}$ & $\begin{array}{l}1 \\
0 \\
0 \\
1\end{array}$ & $\begin{array}{l}24 \\
40 \\
1 \\
65\end{array}$ & $\begin{array}{l}25 \\
40 \\
1 \\
66\end{array}$ & $\begin{array}{l}55.5 \\
54.5 \\
0.5 \\
110.5\end{array}$ \\
\hline
\end{tabular}

(A): TERTIARY SILICIFIED LIMESTONE (CHERT AND SHALE); (B): INCLUDES 1 FRAgMENT OF CONCRETE

14 Finally, the clearing of the experimental plot gave also detailed information about the spatial distribution of the rock fragment cover. In 1999, 95\% of all removed rock fragments were part of a clear polygonal pattern (Nyssen et al., 2000). Newly appearing embedded rock fragments in 2000 and 2001 follow the same pattern. The reason why the polygonal crack bundles and the distribution of rock fragments converge is that a big majority of the latter are resting close to or within the sides of open cracks (Fig. 4), but visible from the soil surface. Cattle trampling could cause this distribution, the rock fragments being pushed into the open cracks. When the soil is dry and hard, this might be possible for small debris, but difficult for larger rock fragments. Furthermore, our 
observations show that rock fragments located close to the surface are generally embedded in the sides of cracks and not lying in the open space of a crack. Finally, the large rock fragments can only be pushed into a muddy soil. But during the rainy season, the cracks are closed and the distribution of rock fragments pushed into the soil cannot reflect the configuration of cracks opening later. Moreover, a by-law prohibits cattle from entering the area during the wet period.

Figure 4. Distribution of embedded rock fragments in the observation circle (radius: $5 \mathrm{~m}$ ) in January 2001 at Enda Maryam and its spatial relationship with large crack patterns.

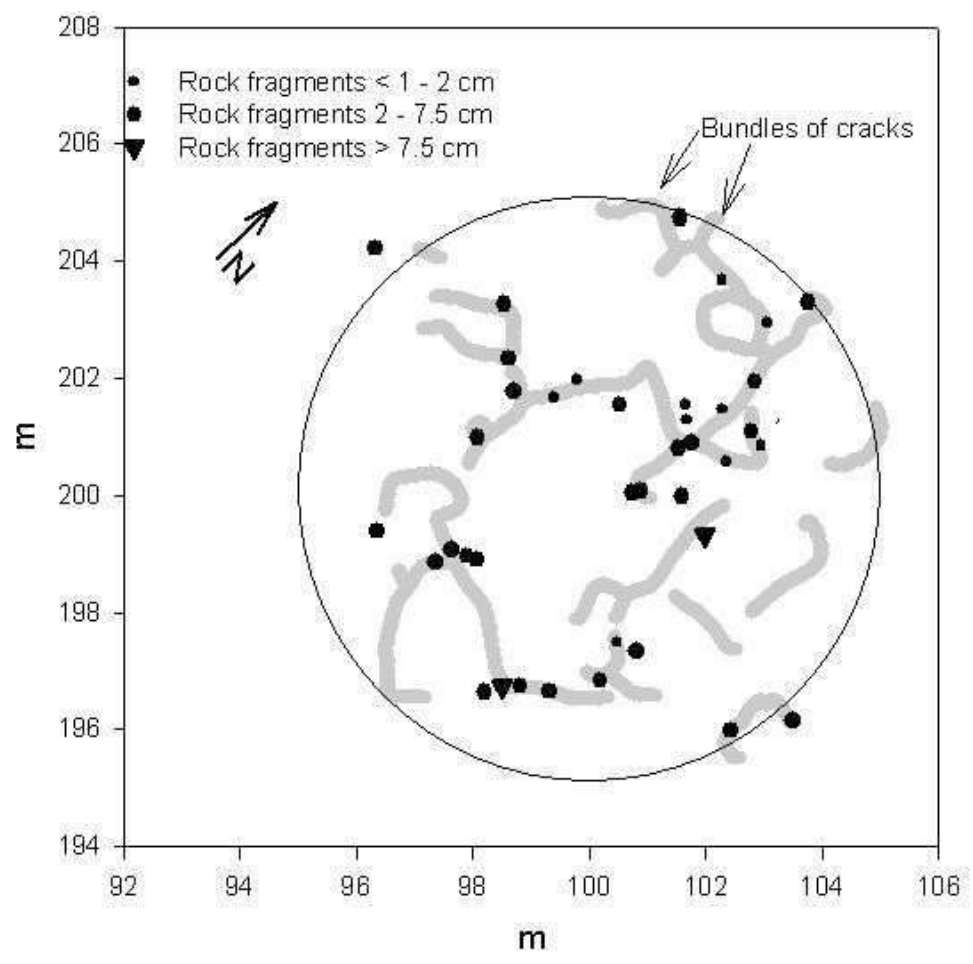

ROCK FRAgMENT AND CRACK POSITION WERE MEASURED INDEPENDENTLY BY THEODOLITE.

The embedded position of the rock fragments makes it also difficult to consider their distribution as a 'sorted stone net' (Ahnert, 1994), resulting from rock fragment movement at the surface by small impulses such as trampling. It is thus hypothesised that the spatial distribution of rock fragments on this site reflects the preferential loci where rock fragments are squeezed out of Vertisols, i.e. along vertical cracks concentrated along the edges of the polygonal structures. These are also the loci where clayey material from the lower B-horizon is squeezed upwards to the surface along chimneys (Dudal \& Eswaran, 1988; Wilding et al., 1990).

\section{Conclusions}

Four points have to be emphasised with respect to the formation of a rock fragment mantle on top of the Vertisol at Enda Maryam:

1. The concentration of rock fragments on top of the Vertisol near Enda Maryam is explained by a vertical upward movement because (a) rock fragments annually appear at the surface of a $78.5-\mathrm{m}^{2}$ circular plot at a rate (Table 1) and in positions, impossible to be due to lateral 
arrival over the soil surface, and (b) the lithology of the rock fragments and the typology of the stony archaeological artefacts fits with the content of layers underneath the Vertisol.

2. The measured rate of upward rock fragment movement over the years 2000 and 2001 is 0.11 $\mathrm{kg} \mathrm{m}-2 \mathrm{y}$-1. From data collected in an earlier study (Nyssen et al., 2002a), we estimated rock fragment cover in several Vertisol areas at some $100 \mathrm{~kg} \mathrm{~m}-2$. This suggests that the development of these rock fragment covers needed several centuries to several thousands of years.

3. The process of upsqueezing is under discussion. As mentioned by Deckers et al. (2001), the appearance of rock fragments at the surface of Vertisols is generally related to the process of pedoturbation, a mechanical mixing of surface and sub-surface soil. Rock fragments from a certain depth in the Vertisol can theoretically arrive at the surface in several ways. The first way is that rock fragments are transported along slickensides. It is very probable that this happens, but it seems at first sight impossible that this type of transport can move rock fragments to the surface. It has been shown (Yaalon \& Kalmar, 1978) that slickensides can only originate at a certain depth, depending on the proportion of normal over tangential stresses, on the bulk density of the soil and on the moisture regime. The second possibility is transport of rock fragments within upward oriented clay «streams» (chimneys or diapirs) (Coulombe et al., 1997). A third way to move rock fragments to the surface is explained by swelling and shrinking as a result of a wetting front, penetrating the soil from its surface (Yaalon \& Kalmar, 1978). The observations at Enda Maryam suggest that still other factors might be at stake. The fact that nearly all «embedded» (Table 1) rock fragments are seated within the wall of subvertical desiccation cracks, indicates that the rising to the surface of rock fragments from deeper in the soil profile happens along such cracks. It has to be explored if there exists a relation between the slickensides, the chimneys and the directions from where a soil becomes wetted at the onset of the rainy season on one hand, and the pattern of subvertical deep desiccation cracks on the other hand.

4. The observations regarding the upsqueezing of rock fragments and prehistoric lithic artefacts are important for archaeology, where it comes to the recognition of in situ artefact levels. It shows that artefacts, being part of the rock fragment cover on top of the Vertisol at Enda Maryam, are in a false, postdepositional, stratigraphic context. They belong originally to colluvial deposits, probably of early- or pre-Holocene times, on top of which the Vertisols are resting. This might urge the revisiting of archaeological sites where «levels» of artefacts occur above, within and below fossil Vertisols.

\section{BIBLIOGRAPHY}

AHMAD N. (1996), «Occurrence and distribution of Vertisols», in AHMAD N., MERMUT A. (eds.), Vertisols and technologies for their management, Elsevier, Amsterdam, pp. 1-41.

AHNERT F. (1994), «Modelling the development of non-periglacial sorted nets», Catena, 23, pp. 43-63.

ARKIN Y., BEYTH M., DOW D.B., LEVITTE D., TEMESGEN HAILE, TSEGAYE HAILU (1971), Geological map of Mekele sheet area ND 37-11, Tigre province, 1:250.000, Imperial Ethiopian Governement, Ministry of Mines, Geological survey, Addis Ababa. 
BEYTH M. (1972), «Paleozoic-Mesozoic sedimentary basin of Makalle outlier», American Association of Petroleum Geologists Bulletin, 56, pp. 2426-2439.

BLOKHUIS W. (1982), «Morphology and genesis of Vertisols», in KUMAR K. (ed.), Trans. 12th Inter. Cong. of Soil Science: Vertisols and rice soils in the tropics, Indian society of soil science, New Delhi, 3, pp.23-47.

BRANCACCIO L., CALDERONI G., COLTORTI M., DRAMIS F. (1997), «Phases of soil erosion during the Holocene in the Highlands of Western Tigray (Northern Ethiopia): a preliminary report», in BARD K. (Ed.), The environmental history and human ecology of Northern Ethiopia in the Late Holocene, Istituto Universitario Orientale, Napoli, pp. 30-48.

COULOMBE C.E., WILDING L.P., DIXON J.B. (1997), «Overview of Vertisols: characteristics and impacts on society», Advances in Agronomy, 57, pp. 289-375.

DECKERS J., SPAARGAREN O., NACHTERGAELE, F. (2001), «Vertisols: genesis, properties and soilscape management for sustainable development», in SYERS J.K., PENNING DE VRIES F.W.T., NYAMUDEZA P. (eds.), The sustainable management of Vertisols, CABI Publishing, New York, pp. 3-20.

DE GEYNDT, K. (2001), Bodemkartering ten behoeve van bodemconserverings-onderzoek in Hagere Selam, Ethiopië, Unpub. M.Sc. thesis, Department of Land Management, University of Leuven.

DUDAL R., ESWARAN H. (1988), «Distribution, properties and classification of Vertisols», in WILDING L.P., PUENTES R. (eds.), Vertisols: their distribution, properties, classification and management, Texas A and M Printing Services, College Station, Texas, pp. 1-22.

ETHIOPIAN MAPPING AUTHORITY (1996), Ethiopia 1:50 000, series ETH 4, sheet 1339 A3 (Abiy Adi), Addis Ababa.

FAO, ISRIC, ISSS (1998), «World reference base for soil resources», Rome, FAO, ISRIC and ISSS, World Soil Resources Reports, 84, 91 p.

GARLAND C. (1980), Geology of the Adigrat Area, Ministry of Mines, Energy and Water Resources, Geological survey of Ethiopia, Addis Ababa, $51 \mathrm{p}$.

HOLE F.D. (1961), «A classification of pedoturbations and some other processes and factors of soil formation in relation to isotropism and anisotropism», Soil Science, 91, pp. 375-377.

HURNI H. (1985), «Erosion - Productivity - Conservation Systems in Ethiopia», Proceedings 4th International Conference on Soil Conservation, Maracay, Venezuela, pp. 654-674.

HUTCHINSON R.W., ENGELS G.G. (1970), «Tectonic significance of regional geology and evaporite lithofacies in northeastern Ethiopia», Phil. Trans. Royal Society of London, A. Mathematical and physical sciences, 267, pp. 313-330.

MACHADO M.J., PEREZ-GONZALEZ A., BENITO G. (1998), «Paleoenvironmental changes during the last 4000 yr in Tigray, Northern Ethiopia», Quaternary Research, 49, pp. 312-321.

MERLA G., ABBATE E., AZZAROLI A., BRUNI P., CANUTI P., FAZZUOLI M., SAGRI M., TACCONI P. (1979), A geological map of Ethiopia and Somalia (1973) 1:2 000000 and comment, University of Florence, Italy.

MITIKU HAILE, FASSIL KEBEDE (1996), «Soil and moisture conservation in the semi-arid areas of Ethiopia», Proc. $3^{\text {rd }}$ Conf. Eth. Soc. Soil Sci., pp. 60-76.

MOHR P. (1963), The geology of Ethiopia, University College of Addis Ababa Press, 270 p. 
NYSSEN J. (2001), Erosion processes and soil conservation in a tropical mountain catchment under threat of anthropogenic desertification - a case study from Northern Ethiopia, Unpub. Ph.D. thesis, Faculty of Sciences, University of Leuven, $380 \mathrm{p}$.

NYSSEN J., MOEYERSONS J., DECKERS J., MITIKU HAILE, POESEN J. (2000), «Vertic movements and the development of stone covers and gullies, Tigray Highlands, Ethiopia», Zeitschrift für Geomorphologie, N.F., 44, 2, pp. 145-164.

NYSSEN J., MITIKU HAILE, POESEN J., DECKERS J., MOEYERSONS J. (2001), «Removal of rock fragments and its effect on soil loss and crop yield, Tigray, Ethiopia», Soil Use and Management, 17, pp. 179-187.

NYSSEN J., POESEN J., MOEYERSONS J., LAVRYSEN E., MITIKU HAILE, DECKERS J. (2002a), «Spatial distribution of rock fragments in cultivated soils in northern Ethiopia as affected by lateral and vertical displacement processes», Geomorphology, 43, 1-2, pp. 1-16.

NYSSEN J., MOEYERSONS J., POESEN J., DECKERS J., MITIKU HAILE (2002b), «The environmental significance of the remobilisation of ancient mass movements in the Atbara-Tekeze headwaters (Northern Ethiopia)», Geomorphology, in press.

PHILLIPSON L. (2000), «Early and Middle Stone Ages», in PHILLIPSON D. (Ed.), Archaeology at Aksum, Ethiopia, 1993-7, London, The British Institute in Eastern Africa \& The Society of Antiquaries, 2 volumes, $538 \mathrm{p}$.

PHILLIPSON L. (2001), Personal communication, The British Institute in Eastern Africa, London. POESEN J., LAVEE H. (1994), «Rock fragments in top soils: significance and processes», Catena, 23, pp. 1-28.

POESEN J., TORRI D., BUNTE K. (1994), «Effects of rock fragments on soil erosion by water at different spatial scales: a review», Catena, 23, pp. 141-166.

RÖMKENS M. (1985), «The soil erodibility factor: a perspective», in EL-SWAIFY S., MOLDENHAUER W., LO A., Soil erosion and conservation, Soil Conservation Society of America, Ankeny, Iowa, pp. 445-461.

WILDING L.P., WILLIAMS D., MILLER W., COOK T., ESWARAN H. (1990), «Close interval spatial variability of Vertisols: A case study in Texas», in KIMBLE J.M. (ed.), Proc. Sixth Int. Soil Correlation Meeting (ISCOM). Characterisation, classification and utilisation of cold Aridisols and Vertisols, USDA Soil Conservation Service, National Soil Survey Center, Lincoln, NE, pp. 232-247.

WISCHMEIER W.H., SMITH D.D. (1978), Predicting rainfall erosion losses: a guide to conservation planning, Agriculture Handbook 537, United States Department of Agriculture, Washington, 58 p.

YAALON D.H, KALMAR D. (1978), «Dynamics of cracking and swelling clay soils: displacements of skelettal grains, optimum depth of slickensides and rate of intrapedonic turbation», Earth Surface Processes, 3, pp. 31-42.

\section{ABSTRACTS}

The rock fragment cover of Vertisols and soils with vertic properties in the Northern Ethiopian Highlands is clearly in a stage of development. On a Vertisol near Enda Maryam Korar (Tigray), the rapid appearance at the surface of new rock fragments after field clearing has been monitored. This paper analyses the phenomenon of the upsqueezing of rock fragments in relation to the active polygonal structures of the Vertisols. Rock fragments, appearing yearly at the top of the Vertisol are shown to belong lithologically to deposits underlying the Vertisols. 
Given this stratigraphic situation and the activity of Vertisols in the study area, the rock fragment covers are thought to be squeezed up as a consequence of argillipedoturbation accompanying swell-shrink cycles in the Vertic horizon. The spatial distribution of upsqueezed rock fragments closely follows the polygonal pattern of crack bundles on top of the Vertisol. Based on yearly measurements of rock fragments appearing at the surface of a $78.5 \mathrm{~m}^{2}$ cleared area, it is estimated that, on average, one rock fragment $(0.11 \mathrm{~kg})$ is squeezed up to the surface per $\mathrm{m}^{2}$ per year. The mechanisms of this vertical transport come under discussion and have to explain why subvertical desiccation cracks are the loci of rock fragment appearance at the surface.

La couverture pierreuse des vertisols et autres sols aux propriétés vertiques sur les Hauts Plateaux du nord de l'Ethiopie se développe activement. Nous avons mesuré l'apparition rapide de nouvelles pierres après le nettoyage de la surface d'un vertisol près d'Enda Maryam Korar (Tigré). Cet article analyse le phénomène du transport vertical de pierres vers la surface en relation avec les structures polygonales actives des vertisols. La lithologie des pierres qui apparaissent annuellement à la surface du vertisol correspond aux dépôts sous-jacents à ce dernier. $\mathrm{Au}$ vu de cette situation stratigraphique et de l'activité des vertisols dans la région d'étude, on estime que les couvertures pierreuses résultent de l'argillipédoturbation qui accompagne les cycles d'humidification et de dessèchement dans l'horizon vertique. La distribution spatiale des pierres correspond étroitement à la trame polygonale des faisceaux de fissures à la surface du vertisol. Sur base de relevés annuels de pierres apparaissant à la surface d'une aire de $78.5 \mathrm{~m}^{2}$, nettoyée au préalable, on estime qu'en moyenne une pierre $(0.11 \mathrm{~kg})$ apparaît à la surface par $\mathrm{m}^{2}$ par an. Prenant en compte le fait que les fissures de dessiccation subverticales soient les lieux d'apparition des pierres à la surface, les mécanismes de ce transport vertical sont discutés.

\section{INDEX}

Mots-clés: argillipédoturbation, couverture pierreuse, Ethiopie, structures polygonales, vertisols

Keywords: argillipedoturbation, Ethiopia, polygonal structures, rock fragment cover, Vertisols

\section{AUTHORS}

\section{JAN NYSSEN}

Laboratory for Experimental Geomorphology, K.U. Leuven, Belgium; Mekelle University, Ethiopia, jan.nyssen@geo.kuleuven.ac.be

\section{JAN MOEYERSONS}

Royal Museum for Central Africa, Tervuren, Belgium

\section{JEAN POESEN}

Laboratory for Experimental Geomorphology, K.U. Leuven, Belgium

\section{MITIKU HAILE}

Mekelle University, P.O.Box 231, Mekelle, Ethiopia 
JOZEF A. DECKERS

Laboratory for Experimental Geomorphology, K.U. Leuven, Belgium 